\title{
Impact of smoking on multiple primary cancers survival: a retrospective analysis
}

\author{
A. Romaszko-Wojtowicz ${ }^{1}$ (1) - A. Buciński ${ }^{2}$ A. Doboszyńska ${ }^{1}$
}

Received: 4 January 2018 / Accepted: 8 March 2018 / Published online: 17 March 2018

(c) The Author(s) 2018

\begin{abstract}
According to available literature, active tobacco smoking enhances the risks of recurrence and development of new primary malignancies. Smoking also shortens the survival period for patients with a diagnosed neoplastic disease. Medical records of 1622 patients hospitalized at the Center for Pulmonary Diseases from January 2013 till March 2017 were retrospectively analyzed, out of which 741 cases with a diagnosis of at least one primary cancer were selected, including 111 patients with multiple primary malignancies. Survival time, the impact of smoking on cancer development and the influence of smoking cessation on the prognosis of the development of new malignancies were analyzed. The incidence of multiple primary malignancies in the population of cancer patients amounted to $14.98 \%$. In the group of smokers, those who ceased smoking developed the second primary malignancy later as compared to those who did not: the period between the first and the new cancer was 11.55 years (SD 7.24) for those who quit smoking, whereas for those who continued to smoke after their first cancer diagnosis it was 6.10 years ( $\operatorname{SD} 8.62)(p=0.005)$. It was revealed that patients who had never smoked lived longer than those who had continued to smoke $(p=0.004)$ and that those who had ceased smoking had a longer survival time than those who had not $(p=0.027)$. Ceasing smoking after the first cancer diagnosis prolongs the time before a new malignancy develops and is diagnosed, as well as the total survival time after the first cancer diagnosis.
\end{abstract}

Keywords Multiple malignancies $\cdot$ Smoking $\cdot$ Survival time $\cdot$ Lung cancer

\section{Introduction}

The development of medicine contributes to increased detection rates of neoplastic diseases and prolongs survival time for cancer patients. Currently it is estimated that approximately $50 \%$ of patients with a diagnosed malignant cancer will survive about 10 years following the diagnosis [1]. This patient population, however, is at risk of developing new malignancies.

Multiple primary cancers (MPCs) are defined as at least two independent, histologically confirmed malignancies that develop within the same or different organs, simultaneously

A. Romaszko-Wojtowicz romaszkoa@gmail.com

1 Department of Pulmonology, Faculty of Health Sciences, Collegium Medicum, University of Warmia and Mazury in Olsztyn, Jagiellońska 78, 10-357 Olsztyn, Poland

2 Department of Biopharmacy, Ludwik Rydygier Collegium Medicum in Bydgoszcz, Nicolaus Copernicus University in Toruń, Bydgoszcz, Poland or consecutively (definition sourced from the National Cancer Registry) [2]. According to the time criterion, MPCs can be divided into synchronous, i.e., new malignancies that develop within 6 months, and metachronous, i.e., when a new malignancy develops after 6 months [3]. The incidence of MPCs in the general population ranges from 0.75 to $11 \%$ [4-6].

The likelihood of developing new primary malignancies in the cancer patient population is higher than the incidence of primaries in the general population. The probability that a new malignancy will develop increases along with the longer survival time following the treatment of the first one. Consequently, patients diagnosed with the first cancer prior to the age of 60 are at a higher risk, as are patients with earlystage primary cancers, whose chances for effective treatment are high. Patients with a history of a neoplastic disease are at a higher risk of developing a new malignancy. This risk increases by $14 \%$ [7]. It has been reported that in patients who survived more than 10 years following the diagnosis of the first cancer of the respiratory system, the risk of developing a new malignancy rises by $49 \%$ [8]. This is influenced, 
i.e., by previous chemotherapy and radiation therapy—both proven to be oncogenic factors.

New malignancies are also influenced by habitual smoking. It has been reported that in patients who continue their addiction after the first cancer diagnosis the risk of developing smoking-related cancers increases by $35 \%$ [9]. Active tobacco smoking increases the risk of recurrence and of the new neoplastic process, but it also causes complications during cancer treatment [10]. It has also been established that smoking increases the MPCs risk [11].

The aim of this work was the assessment of the survival time and the impact of smoking on the prognosis in patients with diagnosed MPCs.

\section{Material and method}

\section{Study population}

We conducted the retrospective analysis of data collected from patients hospitalized between January 2013 and March 2017 at the Center for Pulmonary Diseases in Olsztyn (Poland). The examination of 1622 medical records revealed 741 patients with at least one cancer. Next only those cases in which a new malignancy was confirmed histologically were selected. The inclusion criteria were met by 111 patients: 74 men and 37 women. In 98 cases, lung cancer was the last detected malignancy.

\section{Methodology}

The following parameters were analyzed for each patient: the number of primary malignancies, time of each cancer development, time interval between each new malignancy, the presence of risk factors, such as: tobacco smoking, exposure to harmful agents in the workplace, family history of cancer, other coexisting diseases, survival time and the results of basic laboratory tests (complete blood count, creatinine, GFR, potassium, sodium).

MPCs were determined based on the criteria developed by Warren and Gates in 1944, but still in use. These criteria assume that both neoplastic processes differ in the histologic type and site (they are at least $2 \mathrm{~cm}$ apart) and must produce separate metastases [12]. Based on the time criteria, MPCs were divided into synchronous cancers and metachronous cancers.

A non-smoker was defined as a person who had never smoked or who had smoked fewer than 100 cigarettes (5 packs) during an entire lifetime. A person who ceased smoking was defined as a person who had smoked at least 100 cigarettes during a lifetime but discontinued smoking and did not smoke when the study was conducted $[13,14]$.
Family history of cancer was assumed positive when cancer was diagnosed in first-degree relatives (parents, brothers, sisters, daughters, sons).

The risk of MPCs was estimated based on the number of patients with MPCs in relation to all patients hospitalized due to cancer. Total survival time was calculated beginning from the date of the first cancer diagnosis to the day of death or last observation.

The risk of exposure to harmful agents in the workplace included exposure to: wood dust, pesticides, herbicides, exhaust fumes, asbestos, artificial mineral fibers, metal compounds etc. [15-18]. Patients with lung cancer diagnosed as the last malignancy were termed as 'final lungs,' and those whose last detected malignancy was different from lung cancer were assigned to the group of 'non-final lungs.'

\section{Statistical analysis}

Collected data were analyzed with Dell STATISTICA software (data analysis software system, version 13. software. dell.com). The assumption of normality was tested with the Shapiro-Wilk test. Levene's test was used to assess the equality of variances. Parametric tests were employed when the assumptions of normality and equality of variances were met. The Student's t-test was used to compare two groups, and three or more groups were compared using the analysis of variance ANOVA and post hoc analysis with the LSD test. Nonparametric tests were employed when the assumptions of normality and equality of variance were not met: the Mann-Whitney $U$ test, the Kruskal-Wallis test and a multiple comparison of mean ranks, respectively. The Kaplan-Meier method was used for survival estimate. In all analyses, a significance level of $p=0.05$ was assumed.

\section{Results}

Altogether, $12(10.81 \%)$ cases of synchronous cancers and 99 (89.19\%) cases of metachronous cancers were revealed. The majority of patients—as many as $98(88.29 \%)$ —were smokers. All patients whose last diagnosed malignancy was lung cancer were smokers. The average number of packyears was 34.93 (SD 26.67). Only 3 (2.70\%) out of 111 patients had never smoked. Family history of cancer was detected in $30(27.03 \%)$ patients, and exposure to harmful agents in the workplace was confirmed in 35 (31.53\%) patients. Table 1 presents complete characteristics of the study group.

\section{Coexisting cancers}

The most frequent first cancers in females included: breast cancer $13 / 37$ (35.14\%) and skin cancer 6/37 (16.22\%), 
Table 1 Group characteristics

\begin{tabular}{|c|c|c|c|c|c|}
\hline Variable & Total (111) & Synchronous (12) & Metachronous (99) & Final lungs (98) & Non-final lungs (13) \\
\hline Age at 1 st cancer & $\begin{array}{l}58.50 \\
\text { (SD 11.45) }\end{array}$ & $\begin{array}{l}70.17 \\
\text { (SD 8.59) }\end{array}$ & $\begin{array}{l}60.21 \\
(\mathrm{SD} 11.31)\end{array}$ & $\begin{array}{l}61.92 \\
\text { (SD 11.23) }\end{array}$ & $\begin{array}{l}56.54 \\
\text { (SD 12.49) }\end{array}$ \\
\hline Age at 2 nd cancer & $\begin{array}{l}67.50 \\
(\mathrm{SD} 8.28)\end{array}$ & $\begin{array}{l}70.17 \\
\text { (SD 8.59) }\end{array}$ & $\begin{array}{l}68.39 \\
\text { (SD 8.26) }\end{array}$ & $\begin{array}{l}69.08 \\
\text { (SD 7.77) }\end{array}$ & $\begin{array}{l}64.85 \\
\text { (SD 11.15) }\end{array}$ \\
\hline Female & $\begin{array}{l}37 \\
(33.33 \%)\end{array}$ & $\begin{array}{l}4 \\
(33.33 \%)\end{array}$ & $\begin{array}{l}33 \\
(33.33 \%)\end{array}$ & $\begin{array}{l}28 \\
(28.57 \%)\end{array}$ & $\begin{array}{l}9 \\
(69.23 \%)\end{array}$ \\
\hline Male & $\begin{array}{l}74 \\
(66.67 \%)\end{array}$ & $\begin{array}{l}6 \\
(50.00 \%)\end{array}$ & $\begin{array}{l}68 \\
(68.69 \%)\end{array}$ & $\begin{array}{l}70 \\
(71.43 \%)\end{array}$ & $\begin{array}{l}4 \\
(30.77 \%)\end{array}$ \\
\hline Smoker & $\begin{array}{l}40 \\
(36.04 \%)\end{array}$ & $\begin{array}{l}4 \\
(33.33 \%)\end{array}$ & $\begin{array}{l}36 \\
(36.36 \%)\end{array}$ & $\begin{array}{l}39 \\
(39.80 \%)\end{array}$ & $\begin{array}{l}1 \\
(7.69 \%)\end{array}$ \\
\hline Non-smoker & $\begin{array}{l}3 \\
(2.07 \%)\end{array}$ & $\begin{array}{l}0 \\
(0 \%)\end{array}$ & $\begin{array}{l}3 \\
(3.03 \%)\end{array}$ & $\begin{array}{l}0 \\
(0 \%)\end{array}$ & $\begin{array}{l}3 \\
(23.08 \%)\end{array}$ \\
\hline Ceased smoking before 1 st cancer & $\begin{array}{l}29 \\
(2.13 \%)\end{array}$ & $\begin{array}{l}2 \\
(16.67 \%)\end{array}$ & $\begin{array}{l}27 \\
(27.27 \%)\end{array}$ & $\begin{array}{l}28 \\
(28.57 \%)\end{array}$ & $\begin{array}{l}1 \\
(7.69 \%)\end{array}$ \\
\hline Ceased smoking after 1 st cancer & $\begin{array}{l}20 \\
(18.02 \%)\end{array}$ & $\begin{array}{l}0 \\
(0 \%)\end{array}$ & $\begin{array}{l}20 \\
(20.20 \%)\end{array}$ & $\begin{array}{l}16 \\
(16.33 \%)\end{array}$ & $\begin{array}{l}4 \\
(30.77 \%)\end{array}$ \\
\hline Ceased smoking after 2 nd cancer & $\begin{array}{l}19 \\
(17.12 \%)\end{array}$ & $\begin{array}{l}4 \\
(33.33 \%)\end{array}$ & $\begin{array}{l}15 \\
(15.15 \%)\end{array}$ & $\begin{array}{l}15 \\
(15.31 \%)\end{array}$ & $\begin{array}{l}4 \\
(3077 \%)\end{array}$ \\
\hline COPD & $\begin{array}{l}33 \\
(29.73 \%)\end{array}$ & $\begin{array}{l}2 \\
(16.67 \%)\end{array}$ & $\begin{array}{l}31 \\
(31.31 \%)\end{array}$ & $\begin{array}{l}30 \\
(30.61 \%)\end{array}$ & $\begin{array}{l}3 \\
(23.08 \%)\end{array}$ \\
\hline
\end{tabular}

whereas in males: prostate cancer 17/74 (22.97\%), colorectal cancer $11 / 74$ (14.86\%) and bladder cancer $10 / 74(13.51 \%)$. The second malignancy was most often lung cancer. Table 2 includes a detailed division of the first cancers.

\section{Smoking and survival}

It was revealed that in the case of patients who had stopped smoking the interval between the first and the new cancer was longer as compared to those who had continued to smoke after the first cancer diagnosis and amounted to 11.55 years (SD 7.24) and 6.10 years (SD 8.62) $(p=0.005)$, respectively. Moreover, patients who had never smoked lived statistically significantly longer than those who had continued to smoke $(p=0.004)$ and those who had stopped smoking lived longer than those who had not (0.027).

These data are presented in Fig. 1.

It was also revealed that the average survival time following the first cancer diagnosis was longer for patients who had ceased smoking after diagnosis as compared to those who had continued to smoke ( $p=0.0004)$. It was also proven that life time was prolonged from 6.57 years $(\mathrm{SD}=5.91)$ to 13.75 years (SD 9.14).

\section{Synchronous and metachronous cancers}

The average age of patients diagnosed with synchronous cancers was 70.12 years (SD 8.59). In the case of metachronous cancers, the average age at the first cancer diagnosis was 60.21 years (SD 11.31), and at the new cancer diagnosis-68.39 years (SD 8.26).

Our analysis indicates that patients with synchronous cancers have a worse prognosis than those with metachronous cancers ( $p=0.003$ ) (Fig. 2).

\section{Discussion}

Smoking is a well-known factor that increases the risk of developing new malignancies, cancer recurrence and the appearance of further neoplastic processes. It has been reported that in highly developed countries approximately over 90 and $70 \%$, retrospectively for men and women, of lung cancer diagnoses are associated with smoking. While in other countries, it is approximately 65 and $25 \%$ for men and women [19-22]. Habitual smoking increases the risk of developing lung cancer as compared to non-smoking by 25 times in men and 25.7 in women [23]. The list of smokingrelated cancers is extensive and includes, among others: oral cancer, throat cancer, esophageal cancer, bronchial and lung cancer, bladder cancer and kidney cancer (data sourced from the Centers for Disease Control and Prevention) [24]. Smoking, however, has also other adverse effects. It has been demonstrated that smoking impacts negatively on wound healing and reduces the effectiveness of cancer treatment [25].

In our study population, almost all patients had a history of smoking $(n=108 ; 97.30 \%)$. Baser et al. and Cox LS et al. revealed that $40-50 \%$ of patients diagnosed with lung cancer reported smoking at the time of the final diagnosis 
Table 2 Cancers developed as the first malignancies - division

\begin{tabular}{|c|c|c|c|c|c|c|}
\hline Type & Female (37) & Male (74) & Synchronous (12) & Metachronous (99) & Final lung (98) & Non-final lung (13) \\
\hline Lymphoma & $\begin{array}{l}1 \\
(2.70 \%)\end{array}$ & $\begin{array}{l}1 \\
(1.35 \%)\end{array}$ & $\begin{array}{l}0 \\
(0 \%)\end{array}$ & $\begin{array}{l}2 \\
(2.02 \%)\end{array}$ & $\begin{array}{l}1 \\
(1.02 \%)\end{array}$ & $\begin{array}{l}1 \\
(7.69 \%)\end{array}$ \\
\hline Blood & $\begin{array}{l}1 \\
(2.70 \%)\end{array}$ & $\begin{array}{l}1 \\
(1.35 \%)\end{array}$ & $\begin{array}{l}0 \\
(0 \%)\end{array}$ & $\begin{array}{l}2 \\
(2.02 \%)\end{array}$ & $\begin{array}{l}2 \\
(2.04 \%)\end{array}$ & $\begin{array}{l}0 \\
(0 \%)\end{array}$ \\
\hline Skin & $\begin{array}{l}6 \\
(16.22 \%)\end{array}$ & $\begin{array}{l}8 \\
(10.81 \%)\end{array}$ & $\begin{array}{l}2 \\
(16.67 \%)\end{array}$ & $\begin{array}{l}12 \\
(12.12 \%)\end{array}$ & $\begin{array}{l}12 \\
(12.24 \%)\end{array}$ & $\begin{array}{l}2 \\
(15.38 \%)\end{array}$ \\
\hline Head and neck & $\begin{array}{l}3 \\
(8.11 \%)\end{array}$ & $\begin{array}{l}5 \\
(6.76 \%)\end{array}$ & $\begin{array}{l}2 \\
(16.67 \%)\end{array}$ & $\begin{array}{l}6 \\
(6.06 \%)\end{array}$ & $\begin{array}{l}8 \\
(8.16 \%)\end{array}$ & $\begin{array}{l}0 \\
(0 \%)\end{array}$ \\
\hline Larynx & $\begin{array}{l}4 \\
(10.81 \%)\end{array}$ & $\begin{array}{l}9 \\
(12.16 \%)\end{array}$ & $\begin{array}{l}2 \\
(16.67 \%)\end{array}$ & $\begin{array}{l}11 \\
(11.11 \%)\end{array}$ & $\begin{array}{l}13 \\
(13.27 \%)\end{array}$ & $\begin{array}{l}0 \\
(0 \%)\end{array}$ \\
\hline Breast & $\begin{array}{l}13 \\
(35.14 \%)\end{array}$ & $\begin{array}{l}0 \\
(0 \%)\end{array}$ & $\begin{array}{l}0 \\
(0 \%)\end{array}$ & $\begin{array}{l}13 \\
(13.13 \%)\end{array}$ & $\begin{array}{l}10 \\
(10.20 \%)\end{array}$ & $\begin{array}{l}3 \\
(23.08 \%)\end{array}$ \\
\hline Lung & $\begin{array}{l}1 \\
(2.70 \%)\end{array}$ & $\begin{array}{l}8 \\
(10.81 \%)\end{array}$ & $\begin{array}{l}2 \\
(16.67 \%)\end{array}$ & $\begin{array}{l}7 \\
(7.07 \%)\end{array}$ & $\begin{array}{l}8 \\
(8.16 \%)\end{array}$ & $\begin{array}{l}1 \\
(7.69 \%)\end{array}$ \\
\hline Stomach & $\begin{array}{l}0 \\
(0 \%)\end{array}$ & $\begin{array}{l}1 \\
(1.35 \%)\end{array}$ & $\begin{array}{l}0 \\
(0 \%)\end{array}$ & $\begin{array}{l}1 \\
(1.01 \%)\end{array}$ & $\begin{array}{l}1 \\
(1.02 \%)\end{array}$ & $\begin{array}{l}0 \\
(0 \%)\end{array}$ \\
\hline Colon & $\begin{array}{l}2 \\
(5.41 \%)\end{array}$ & $\begin{array}{l}11 \\
(14.86 \%)\end{array}$ & $\begin{array}{l}2 \\
(16.67 \%)\end{array}$ & $\begin{array}{l}11 \\
(11.11 \%)\end{array}$ & $\begin{array}{l}13 \\
(13.27 \%)\end{array}$ & $\begin{array}{l}0 \\
(0 \%)\end{array}$ \\
\hline Kidney & $\begin{array}{l}0 \\
(0 \%)\end{array}$ & $\begin{array}{l}3 \\
(4.05 \%)\end{array}$ & $\begin{array}{l}0 \\
(0 \%)\end{array}$ & $\begin{array}{l}3 \\
(3.03 \%)\end{array}$ & $\begin{array}{l}3 \\
(3.06 \%)\end{array}$ & $\begin{array}{l}0 \\
(0 \%)\end{array}$ \\
\hline Bladder & $\begin{array}{l}1 \\
(2.70 \%)\end{array}$ & $\begin{array}{l}10 \\
(13.51 \%)\end{array}$ & $\begin{array}{l}1 \\
(8.33 \%)\end{array}$ & $\begin{array}{l}10 \\
(10.10 \%)\end{array}$ & $\begin{array}{l}10 \\
(10.20 \%)\end{array}$ & $\begin{array}{l}1 \\
(7.69 \%)\end{array}$ \\
\hline Uterus & $\begin{array}{l}3 \\
(8.11 \%)\end{array}$ & $\begin{array}{l}0 \\
(0 \%)\end{array}$ & $\begin{array}{l}0 \\
(0 \%)\end{array}$ & $\begin{array}{l}3 \\
(3.03 \%)\end{array}$ & $\begin{array}{l}1 \\
(1.02 \%)\end{array}$ & $\begin{array}{l}2 \\
(15.38 \%)\end{array}$ \\
\hline Ovary & $\begin{array}{l}2 \\
(5.41 \%)\end{array}$ & $\begin{array}{l}0 \\
(0 \%)\end{array}$ & $\begin{array}{l}0 \\
(0 \%)\end{array}$ & $\begin{array}{l}2 \\
(2.02 \%)\end{array}$ & $\begin{array}{l}1 \\
(1.02 \%)\end{array}$ & $\begin{array}{l}1 \\
(7.69 \%)\end{array}$ \\
\hline Prostate & $\begin{array}{l}0 \\
(0 \%)\end{array}$ & $\begin{array}{l}17 \\
(22.97 \%)\end{array}$ & $\begin{array}{l}1 \\
(8.33 \%)\end{array}$ & $\begin{array}{l}16 \\
(16.16 \%)\end{array}$ & $\begin{array}{l}15 \\
(15.31 \%)\end{array}$ & $\begin{array}{l}2 \\
(15.38 \%)\end{array}$ \\
\hline
\end{tabular}

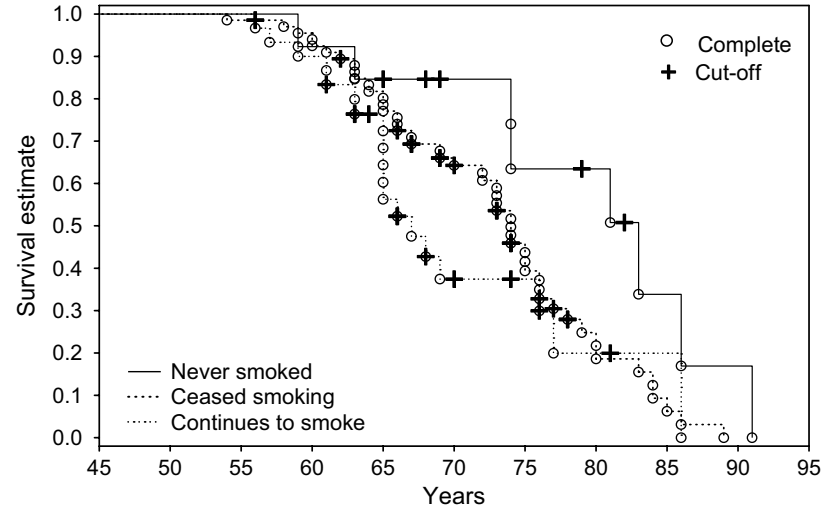

Fig. 1 The Kaplan-Meier survival after the first cancer estimate in relation to smoking

[26, 27]. In our study $(n=39), 35.14 \%$ of patients ceased smoking after the first or new cancer diagnosis, whereas $(n=40) 36.04 \%$ of patients continued to smoke actively (Table 1). As Fig. 1 indicates, patients who stopped smoking after the first cancer diagnosis lived longer than those who continued to smoke. Khuder et al. demonstrated that

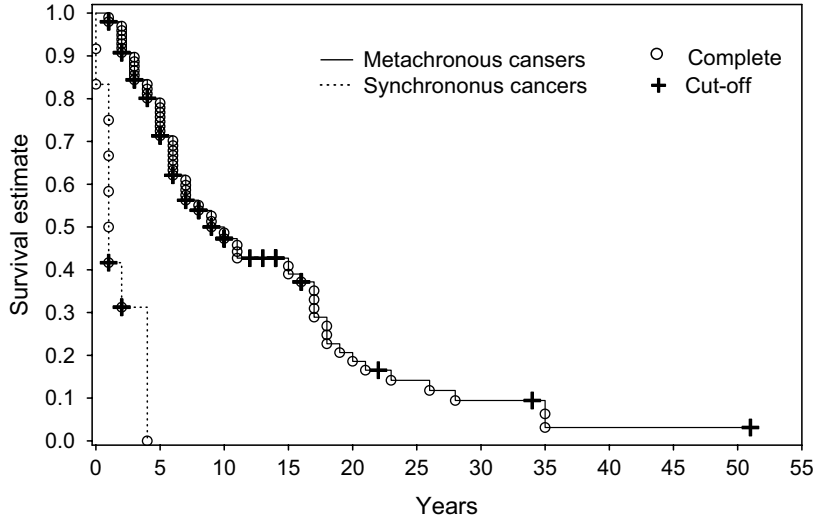

Fig. 2 The Kaplan-Meier survival after the first cancer estimate for patients with metachronous and synchronous cancers

smoking cessation before the first cancer diagnosis reduced the risk of primary lung tumor of all major histologic types and the most significant reduction was observed in the case of small-cell lung carcinoma and squamous cell carcinoma [28]. No unequivocal evidence exists, however, that smoking cessation after lung cancer diagnosis can improve survival 
rates. Most published reports on the effect of smoking on survival of patients with describe patients whose disease is not yet advanced. Consequently, in the long-term perspective these results may differ substantially as compared to studies referring to patients in the advanced stages of the disease. Parson et al. revealed that the continuation of smoking was associated with an increased risk of death by $19 \%$ as compared to patients who had ceased smoking; however, they did not achieve statistical significance [29].

In our study, we demonstrate that the longest survival period is observed in the group of non-smokers and decreases in the group of patients who ceased smoking after the first cancer diagnosis and those who continued to smoke, respectively (Fig. 1). The analyzed data also indicate that the interval between the first and new cancer diagnoses is longer in the case of patients who ceased smoking as compared to those who continued to smoke habitually. Moreover, the average survival time after the first cancer diagnosis is longer for patients who ceased smoking in comparison with those who continued (Fig. 2). According to our best knowledge, no reports published thus far have demonstrated directly that smoking cessation after malignant cancer diagnosis can prolong the interval between the first and new cancer. Survival prognoses have focused mainly in comparisons with smokers and non-smokers.

It is well known that smoking leads to the initial mutations of normal cells and contributes to their further proliferation [30, 31]. Substances contained in tobacco smoke such as: benzoapyrenes, polycyclic aromatic hydrocarbons and nitrosamines, generate reactive oxygen forms through their toxic effect on DNA, and consequent mutations in K-RAS and p53 genes [32]. In their overview, Schaal et al. also described other gene mutations resulting from exposure to tobacco smoke [33]. According to another hypothesis, nicotine plays a significant role in angiogenesis and thus promotes tumor growth [34].

Lung cancer was the most frequently developed new primary malignancy in the analyzed patients. It was the first primary only in 9 cases $(8.11 \%$ ) (Table 2 ). In our study population, all patients who developed lung cancer as their last malignancy were smokers. Ferlay et al. demonstrated that $15-25 \%$ of patients diagnosed with lung cancer had never smoked [35]. However, it was also revealed that in developed countries characterized with a high proportion of smokers about $90 \%$ of lung cancers were tobacco-related [18]. Differences between these reports and our results may stem from the fact that patients from the Warmia and Mazury Voivodeship are hospitalized in our center. According to the Central Statistical Office, this region occupies the third place in terms of frequency of smoking in Poland [36].

In our study, we also demonstrate that the survival period for patients with synchronous cancers is shorter than those with metachronous cancers (Fig. 2). This result is in line with other reports [37]. Aziz et al. showed that a 5-year survival of patients with lung cancer as a new malignancy amounted to $44 \%$ as compared to $10 \%$ for patients with synchronous cancers [38]. It was also reported that smoking cessation may decrease the risk of multiple synchronous lung cancers [39].

Mehdi et al. revealed that synchronous cancers were more aggressive and resistant to treatment, hence the worse prognosis [40]. A simultaneous development of several malignancies-synchronous cancers-requires more aggressive treatment, often affecting several organs, consequently survival estimates for such patients are frequently worse.

\section{Study limitation}

This study is a retrospective analysis based on a limited number of patients. It is a one-center study conducted in the Center for Pulmonary Diseases in which most patients are hospitalized due to pulmonary diseases and the majority of diagnosed malignancies are lung cancers. Consequently, our analysis refers mainly to patients with MPCs when a new malignancy is lung cancer. Still, it is significant that survival estimates for patients with lung cancer are poor: only about $16 \%$ of patients survive for 5 years and the majority of patients undergo palliative treatment following their diagnosis [41]. Lung cancer is diagnosed when the disease is already in an advanced stage. In this case, despite newly developed treating methods such as: molecular-targeting agents and immunotherapies, chemotherapy and radiotherapy play major roles in the treatment. The percentage of patients with primary lung cancer and an additional cancer increased, at the Hospital del Mar in Barcelona, from 7.4\% in the period 1990-1995 to $17.6 \%$ in the period 2000-2004 [42]. Thus, the majority of these patients do not live long enough to develop a new malignancy, and lung cancer is most often the last detected malignancy.

The presented data unequivocally indicate that smoking cessation brings about evident advantages. Consequently, data related to the succession order of MPCs (lung cancer being the last malignancy) may partly stem from the profile of patients hospitalized in our center. Yet the data concerning the characteristics of a given patient could not have been falsified.

\section{Conclusions}

1. The incidence of MPCs in the population of cancer patients amounts to $14.98 \%$. However, it is $6.84 \%$ in the total study population.

2. Survival time and the interval between the first and new cancer development are longer for patients who never 
smoked or ceased smoking as compared to active smokers.

3. Smoking cessation after the first cancer diagnosis prolongs the period of time before a new cancer is detected, as well as the total survival time for patients since the first cancer diagnosis.

\section{Compliance with ethical standards}

Conflict of interest The authors declare that they have no conflict of interest.

Ethical approval As it is a retrospective analysis, no ethical approval is required.

Informed consent As it is a blinded retrospective analysis, with no personal data or identified details used in the article, no informed consent is required.

Open Access This article is distributed under the terms of the Creative Commons Attribution 4.0 International License (http://creativeco mmons.org/licenses/by/4.0/), which permits unrestricted use, distribution, and reproduction in any medium, provided you give appropriate credit to the original author(s) and the source, provide a link to the Creative Commons license, and indicate if changes were made.

\section{References}

1. Australian Institute of Health and Welfare (AIHW), Cancer Australia and Australasian Association of Cancer Registries. Cancer survival and prevalescence in Australia: cancer diagnosed from 1982 to 2004 Canberra, Australia, Cancer Series No. 42, Cat. No CAN 38, 2008

2. National Cancer Registry. Multiple primary neoplasms. Krajowy Rejestr Nowotworów. http://onkologia.org.pl/nowotwory-niedo kladnie-okreslone-wtorne-nieokreslonym-umiejscowieniu-nowot wory-mnogie-c76-cc80-c97/. Accessed 06 Aug 2017.

3. Vaamonde P, Martin C, del Rio M, LaBella T. Second primary malignancies in patients with cancer of the head and neck. Otolaryngol Head Neck Surg. 2003;129:65-70. https://doi.org/10.1016/ S0194-59980300476-5.

4. Jiao F, Yao LJ, Zhou J, Hu H, Wang LW. Clinical features of multiple primary malignancies: a retrospective analysis of 72 Chinese patients. Asian Pac J Cancer Prev. 2014;15(1):331-4.

5. Tsukuma H, Fujimoto I, Hanai A, Hiyama T, Kitagawa T, Kinoshita N. Incidence of second primary cancers in Osaka residents, Japan, with special reference to cumulative and relative risks. J Cancer Res. 1994;85(4):339-45.

6. Frodin JE, Ericsson J, Barlow L. Multiple malignant tumors in a national cancer registry-reliability of reporting. Acta Oncol. 1997;36(5):465-9.

7. Liu L, de Vries E, Louwman M, et al. Prevalence of multiple malignancies in the Netherlands in 2007. Int J Cancer. 2011;128(7):1659-67. https://doi.org/10.1002/ijc.25480.

8. Caporaso NE, Dodd KW, Tucker MA. New malignancies following cancer of the respiratory tract. New Malig Among Cancer Surviv SEER Cancer Regist. 1973;1973-2000:145-79.
9. Soerjomataram I, Coebergh JW. Epidemiology of multiple primary cancers. Methods Mol Biol. 2009;471:85-105. https://doi. org/10.1007/978-1-59745-416-2_5.

10. Stewart BW, Cotter PF, Bishop JF. Cancer and tobacco: its effects on individuals and populations. In: Robotin M, Olver I, Girgis A, editors. when cancer crosses disciplines: a physician's handbook. London: Imperial College Press; 2009. p. 1-31.

11. Japan Epidemiology Association. Handbook of epidemiologyepidemiology and prevention of major diseases. Tokyo: Nankodo; 1998.

12. Warren S, Ehrenreich T. Multiple primary malignant tumors and susceptibility to cancer. Cancer Res. 1944;4:554-70.

13. Schoenborn CA, Adams PF. Health behaviors of adults: United States, 2005-2007. National Center for Health Statistics. Vital Health Stat. 2010;10(245):1-132.

14. Daniel M, Keefe FJ, Lyna P, et al. Persistent smoking after a diagnosis of lung cancer is associated with higher reported pain levels. J Pain. 2009;10(3):323-8. https://doi.org/10.1016/j.jpain .2008.10.006.

15. Zlatev Z, Todorova K, Anastasova N, Chuturkova R, Yaneva A, Sabeva Y. Assessment of the working-environment harmful factors and health risk of workers in a nitrogen fertilizer plant. Int Arch Occup Environ Health. 1998;71:97-100.

16. Belpomme D, Irigaray $\mathrm{P}$, Hardell $\mathrm{L}$, et al. The multitude and diversity of environmental carcinogens. Environ Res. 2007;105(3):414 29. https://doi.org/10.1016/j.envres.2007.07.002.

17. Anand P, Kunnumakara AB, Sundaram C, et al. Cancer is a preventable disease that requires major lifestyle changes. Pharm Res. 2008;25(9):2097-116. https://doi.org/10.1007/s 1109 5-008-9661-9.

18. Bhatti P, Newcomer L, Onstad L, et al. Wood dust exposure and risk of lung cancer. Occup Environ Med. 2011;68(8):599-604. https://doi.org/10.1136/oem.2010.060004.

19. Cheng TYD, Cramb SM, Baade PD, Youlden DR, Nwogu C, Reid ME. The international epidemiology of lung cancer: latest trends, disparities, and tumor characteristics. J Thorac Oncol. 2016;11(10):1653-71. https://doi.org/10.1016/j.jtho.2016.05.021.

20. U.S. Department of Health and Human Services. The health consequences of smoking: a report of the surgeon general. Atlanta: U.S. Dept of Health and Human Services, Centers for Disease Control and Prevention; 2004.

21. Jha P, Ramasundarahettige C, Landsman V, et al. 21st-century hazards of smoking and benefits of cessation in the United States. N Engl J Med. 2013;368:341-50. https://doi.org/10.1056/NEJMs a1211128.

22. Ezzati M, Lopez AD. Estimates of global mortality attributable to smoking in 2000. Lancet. 2003;362:847-52.

23. U.S. Department of Health and Human Services. The health consequences of smoking - 50 years of progress: a report of the surgeon general. Atlanta: U.S. Department of Health and Human Services, Centers for Disease Control and Prevention, National Center for Chronic Disease Prevention and Health Promotion, Office on Smoking and Health; 2014. Accessed 20 Feb 2018.

24. Centers for Disease Control and Prevention. Smoking-related cancers. Centers for Disease Control and Prevention. https:// www.cdc.gov/cancer/tobacco/index.htm/. Updated 12 Jan 2017. Accessed 11 Sept 2017.

25. Tsao AS, Liu D, Lee JJ, Spitz M, Hong WK. Smoking affects treatment outcome in patients with advanced non-small cell lung cancer. Cancer. 2006;106:2428-36. https://doi.org/10.1002/ cncr.21884.

26. Baser S, Shi W, Amar D, et al. Smoking cessation after diagnosis of lung cancer is associated with a beneficial effect on performance status. Chest. 2006;130:1784-90. https://doi.org/10.1378/ chest.130.6.1784. 
27. Cox LS, Africano NL, Tercyak KP, Taylor KL. Nicotine dependence treatment for patients with cancer. Cancer. 2003;98:632-44. https://doi.org/10.1002/cncr.11538.

28. Khuder SA, Mutgi AB. Effect of smoking cessation on major histologic types of lung cancer. Chest. 2001;120:1577-83.

29. Parsons A, Daley A, Begh R, Aveyard P. Influence of smoking cessation after diagnosis of early stage lung cancer on prognosis: systematic review of observational studies with meta-analysis. BMJ. 2010;340:b5569. https://doi.org/10.1136/bmj.b5569.

30. Hecht SS. Tobacco smoke carcinogens and lung cancer. J Natl Cancer Inst. 1999;91:1194-210.

31. Alexandrov LB, Seok JuY, Haase K, et al. Mutational signatures associated with tobacco smoking in human cancer. Science. 2016;354(6312):618-22. https://doi.org/10.1126/science.aag0299.

32. Hecht SS. Research opportunities related to establishing standards for tobacco products under the Family Smoking Prevention and Tobacco Control Act. Nicotine Tob Res. 2012;14:18-28.

33. Schaal C, Chellappan SP. Nicotine-mediated cell proliferation and tumor progression in smoking-related cancers. MCR. 2014;12(1):14-23. https://doi.org/10.1158/1541-7786. MCR-13-0541.

34. Heeschen C, Jang JJ, Weis M, et al. Nicotine stimulates angiogenesis and promotes tumour growth and atherosclerosis. Nat Med. 2001;7:833-9. https://doi.org/10.1038/89961.

35. Ferlay J, Shin HR, Bray F, Forman D, Mathers C, Parkin DM. Estimates of worldwide burden of cancer in 2008: GLOBOCAN
2008. Int J Cancer. 2010;127:2893-917. https://doi.org/10.1002/ ijc. 25516 .

36. World Health Organization. Stan zagrożenia epidemia palenia tytoniu w Polsce. Kopenhaga: WHO; 2009.

37. van Rens MTM, Zanen P, de la Rivière $A B$, Elbers HR, van Swieten HA, van Den Bosch JM. Survival in synchronous vs single lung cancer: upstaging better reflects prognosis. Chest. 2000;118(4):952-8.

38. Aziz TM, Saad RA, Glasser J, Jilaihawi AN, Prakash D. The management of second primary lung cancers. A single centre experience in 15 years. Eur J Cardiothorac Surg. 2002;21(3):527-33.

39. Tucker MA, Murray N, Shaw EG, et al. Second primary cancers related to smoking and treatment of small-cell lung cancer. Lung Cancer Working Cadre. J Natl Cancer Inst. 1997;89:1782-8.

40. Mehdi I, Shah AH, Moona MS, et al. Synchronous and metachronous malignant tumours expect the unexpected. J Pak Med Assoc. 2010;60:905-9.

41. Jemal A, Siegel R, Xu J, Ward E. Cancer statistics, 2010. CA Cancer J Clin. 2010;60:277-300. https://doi.org/10.3322/caac.20073.

42. Aguiló R, Macià F, Porta M, Casamitjana M, Minguella J, Novoa AM. Multiple independent primary cancers do not adversely affect survival of the lung cancer patient. Eur J Cardio Thorac Surg. 2008;34:1075-80. https://doi.org/10.1016/j.ejcts.2008.08.004. 